\title{
Strategia unikowego radzenia sobie młodzieży w wieku dorastania w sytuacji konfliktu społecznego w kontekście oceny poznawczej konfliktu i modelującego wpływu rodziców
}

\begin{abstract}
Abstrakt
Celem badań było poszukiwanie osobowościowych i rodzinnych predyktorów strategii unikowego radzenia sobie dorastającej młodzieży w sytuacji konfliktu społecznego. Analiza materiału badawczego wykazała, że sytuacja konfliktu postrzegana jako zagrożenie lub krzywda/strata współwystępuje ze strategią unikowego radzenia sobie młodzieży w sytuacji konfliktu społecznego. Okazało się również, że rodzic stosujący w sytuacji konfliktu społecznego strategię opartą na unikaniu przyczynia się do modelowania u młodzieży strategii unikowego radzenia sobie w sytuacji konfliktu społecznego.
\end{abstract}

Słowa kluczowe: młodzież gimnazjalna, ocena poznawcza, modelowanie zachowania, strategia unikowego radzenia sobie, sytuacja konfliktu społecznego.

\section{The Avoidance Strategy of Adolescents for Coping with a Situation of Social Conflict in the Context of Cognitive Assessment of Conflict and the Modelling Influence of Parents}

\begin{abstract}
The aim of the research was to search for personality and family predictors of avoidance strategies for coping with social conflict situations in adolescents. The analysis of the research material showed that a conflict situation perceived as a threat
\end{abstract}

* Uniwersytet Wrocławski.

Artykuł otrzymano: 27.07.2020; akceptacja: 13.11.2020. 
or harm/loss coexisted with a strategy of avoidance in coping with a social conflict situation in adolescents. It was also found that a parent using a strategy based on avoidance in a social conflict situation contributes to modelling such a strategy for adolescents.

Keywords: junior high school adolescents, cognitive evaluation, modelling of behaviour, strategy of avoidance coping, social conflict situation.

\section{Wprowadzenie}

Sytuacja konfliktu z drugim człowiekiem stanowi jedną z podstawowych sytuacji społecznych w życiu każdego człowieka. Słowo „konflikt” wywodzi się łacińskiego confligere, conflictatio, oznaczającego wpadnięcie na siebie, spór, dyskusję, walkę lub zderzenie dwu czy więcej procesów, sił właściwym istotom żywym. „Wpadnięcie na siebie" może zapoczątkować walkę. Wielu ludziom konflikt niesłusznie kojarzy się wyłącznie z bezpośrednią agresją fizyczną i/lub werbalną oraz towarzyszącą im wrogością, powiększającą istniejące sprzeczności. Większość zjawisk, które można określić jako konflikty interpersonalne, przybiera stosunkowo łagodne formy, np. krótkiej sprzeczki, dyskusji czy debaty (Olubiński 1992). W kontekście stosunków interpersonalnych sytuacja konfliktowa prezentuje pewien rodzaj interakcji pomiędzy partnerami, w której uświadamiają sobie dzielące ich różnice interesów, potrzeb czy dążeń do celów (Balawajder 2010).

Adolescencja jest okresem, w którym młodzież przeżywa różne, często ze sobą sprzeczne dążenia i musi radzić sobie z kierowanymi wobec niej niespójnymi oczekiwaniami społecznymi. Rezultaty badań wskazują, że młodzież w tym okresie za źródło silnego pobudzenia emocjonalnego o negatywnym zabarwieniu uznaje konflikty interpersonalne, do których zalicza konflikt z nauczycielem, sprzeczki z kolegami ze szkoły i z sympatią oraz kłótnie z jednym lub obojgiem rodziców i innymi członkami rodziny (Jaworski 2000; Kobus, Reyes 2000; Miłkowska-Olejniczak 2002; Węglińska 2007). Najbardziej konfliktowymi obszarami w układzie uczeń - nauczyciel są oceny szkolne, nietaktowne zachowanie oraz władczy nacisk i sztywność wymagań (Polak 2010; Miłkowska 2012; Cylkowska-Nowak, Augustyn 2014). Główne powody konfliktów rówieśniczych to zaczepki, zdrada, niedyskrecja, rywalizacja o stopnie w szkole, o względy u płci przeciwnej, o władzę nad klasą i prestiż sportowy (Różańska-Kowal 2004; Polak 2010). W funkcjonowanie rodzin z dorastającymi dziećmi nieuchronnie wpisane są konflikty międzypokoleniowe. Rodzice oceniają, że ich relacje z dorastającymi dziećmi są bardziej burzliwe i konfliktowe w porównaniu z relacjami we wczesnych okresach rozwojowych. Przyczyną konfliktów z członkami rodziny jest potrzeba postawienia na swoim przez młodego człowieka. Poczucie, że decyduje, wybiera i działa samodzielnie. Jednostka taka kształtuje się w sferze ciągłych konfliktów pomiędzy tym, czego pragnie, a tym, czego oczekują od niej rodzice. Wiele konfliktów z rodzicami doty- 
czy codziennych sytuacji - różnic w gustach, w opiniach, na przykład związanych z wynikami w nauce, ubiorem, muzyką, oglądaniem telewizji, korzystaniem z komputera, spędzaniem czasu wolnego czy późnymi powrotami do domu (Jaworski 2000; Gurba 2013; Walęcka-Matyja 2015).

Sytuacja konfliktu społecznego, która zalicza się do kategorii trudnych sytuacji interakcji społecznych, towarzyszy człowiekowi we wszystkich okresach jego życia. Od chwili narodzin każdy człowiek musi uczyć się radzić sobie z trudnościami i wyzwaniami, które przed nim stoją. Sytuacja trudna pobudza go do aktywności ukierunkowanej na odzyskanie równowagi pomiędzy wymaganiami a możliwościami realizacyjnymi podmiotu i/lub poprawę stanu emocjonalnego. Aktywność, którą człowiek podejmuje w trudnej sytuacji, rozpatruje się w konkretnym kontekście sytuacyjnym jako strategię radzenia sobie w aktualnej sytuacji trudnej (Wrześniewski 1996; Heszen-Niejodek 2000). Jak widać, strategią bywa nazwane to, co człowiek robi we wszelkich sytuacjach trudnych, w celu poradzenia sobie z konkretną sytuacją w sposób spontaniczny, wcześniej niezaplanowany. Umiejętność radzenia sobie w sytuacji konfliktu społecznego może przybrać między innymi formę strategii działań destruktywnych (Deutsch, Coleman 2005; Pisula, Sikora 2008; Kłusek-Wojciszke 2009; Borecka-Biernat 2012). Strategie destruktywne w sytuacjach konfliktowych nie są ukierunkowane na rozwiązanie i przezwyciężenie sytuacji konfliktu, pozwalają człowiekowi jedynie obniżać przykre napięcie emocjonalne. Natomiast cel, który sobie początkowo stawiał, przyczyna powstania konfliktu, zostaje zastąpiony innym - osiągnięciem dobrego samopoczucia. Dzieje się to m.in. przez unikanie konfrontacji z sytuacją konfliktu polegające na odraczaniu działań i aktywności, zwlekaniu z podejmowaniem wysiłków zaradczych w kierunku rozwiązywania konfliktu, podjęcia dodatkowych czynności angażujących uwagę i odwracających ją od sytuacji konfliktu (oglądanie telewizji, gra na komputerze, serfowanie po Internecie, słuchanie muzyki, uprawianie sportu, objadanie się, spacer, sen), jak i poszukiwaniu kontaktu z innymi ludźmi. Można powiedzieć, że człowiek przyjmujący strategie destruktywne nie obciąża się trudnościami rozwiązania konfliktu. Nierozwiązany konflikt w dłuższej perspektywie czasowej wywołuje w nim uczucie niezadowolenia, które przyspieszy pojawienie się kolejnego konfliktu. Strategie destruktywnego radzenia sobie w sytuacji konfliktu społecznego są krótkoterminowe, nie uwzględniają w szerszym kontekście dalszych konsekwencji działań.

Liczne badania i potoczna nawet obserwacja wskazują, że dorastająca młodzież dysponuje repertuarem strategii destruktywnego radzenia sobie z sytuacjami konfliktowymi, które mają miejsce w szkole, w relacjach z rówieśnikami czy w domu rodzinnym (Guszkowska i in. 2001; Miłkowska-Olejniczak 2002; Sikora, Pisula 2002). Jest wśród nich strategia unikowa w postaci rezygnacji, niepodejmowania aktywnego działania w obliczu konfliktu, unikania problemu i dystansowania się, np. przez angażowanie się w „bezstresowe” formy aktywności czy szukanie kontaktów interpersonalnych (Jaworski 2000; Miłkowska-Olejniczak 2002; Różań- 
ska-Kowal 2004; Lachowska 2010). Należałoby postawić pytanie, dlaczego młodzież w sytuacjach konfliktu społecznego wybiera strategię destruktywną w postaci unikowego reagowania na trudności? Zdaniem Marii Tyszkowej (1986) w psychologicznym mechanizmie zachowania się człowieka w sytuacjach trudnych szczególną rolę odgrywają schematy (struktury) poznawcze wyznaczające procesy spostrzegania sytuacji zewnętrznej oraz wzorce (modele) reagowania rodziców na trudności.

Schemat poznawczy jest reprezentacją pewnego fragmentu rzeczywistości, w aktywny (przetworzony) sposób odzwierciedlający właściwości obiektu, własne emocje z nim związane oraz uruchamiane wobec niego programy działań (Trzebiński 1985; Wojciszke 1988). Warto podkreślić, że żaden akt regulacyjny nie może dojść do skutku, jeżeli nie opiera się równocześnie na rozpoznaniu tego, co aktualnie się dzieje oraz na wartościowaniu danego zdarzenia. Łączny wynik obu procesów doprowadza do ukształtowania lub wyboru odpowiedniej formy zachowania (Reykowski 1988). To więc, jak człowiek ujmuje świat, jakie są jego postawy i oczekiwania w stosunku do samego siebie, do innych ludzi, do zadań i rezultatów własnej aktywności, określa sposób poznawczego i emocjonalnego percypowania i interpretowania sytuacji trudnej, co zwrotnie wpływa na zachowanie się w tej sytuacji (Tyszkowa 1986).

Aktywność człowieka w sytuacji trudnej zależy w dużej mierze od dokonania przez niego oceny położenia, w jakim się znalazł. Ocena poznawcza sytuacji jest procesem kategoryzacji zdarzeń z punktu widzenia ich znaczenia dla dobrostanu jednostki (Włodarczyk 1999). Ocenie podlegają elementy z otoczenia jednostki, które są istotne dla jej dobrego samopoczucia, a równocześnie oceniane są jako sprzyjająco-pozytywne, niemające znaczenia albo stresujące. Szczególna rola oceny poznawczej zaznacza się podczas trudnych sytuacji, które zakłócają dotychczasowy tok czynności, zagrażają człowiekowi, utrudniają bądź uniemożliwiają mu realizację potrzeb. Zdarzenie stresowe może zostać ocenione jako krzywda/strata (dotyczy poniesionych szkód i strat związanych z ważnymi obiektami i przedmiotami), zagrożenie (odnosi się do podobnych szkód, które jeszcze nie wystąpiły - dopiero mają nastąpić i są antycypowane) i wyzwanie (wskazuje na możliwość opanowania sytuacji trudnej i zyskania czegoś) (Włodarczyk 1999; Włodarczyk, Wrześniewski 2005). Dlatego, aby dowiedzieć się, czy dana sytuacja jest krzywdząca, czy zagrażająca, czy też wyzwalająca dla jednostki, niezbędna jest jej ocena poznawcza. Ocena poznawcza dotyczy doświadczeń subiektywnych, dlatego możliwe są różnice w ocenie tej samej sytuacji trudnej przez różnych ludzi (ocena sytuacyjna), jak również podobna ocena różnych sytuacji przez tę samą osobę (ocena dyspozycyjna) (Włodarczyk, Wrześniewski 2010). Indywidualna ocena wydarzenia wpływa na decyzje jednostki dotyczące możliwości podjęcia działania usuwającego przyczyny sytuacji trudnej lub przynajmniej łagodzącej jej skutki, określanego jako strategia zaradcza (Heszen-Niejodek 2000; Winstok 2007). Tak więc czynnikiem warunkują- 
cym wybór strategii radzenia sobie w trudnych sytuacjach społecznych jest interpretacja zaistniałej sytuacji, czyli realizowana przez jednostkę ocena poznawcza.

Ludzie preferują różne strategie zaradcze w zależności od rodzaju sytuacji i od dokonywanych indywidualnych ocen poznawczych tych sytuacji. Wyniki badań, na które powołują się Mario Mikulicer i Victor Florian (1995), Mark Anshel i Bruce Wells (2000), Kent Kowalski, Peter Crocker i Sharleen Hoar (2005), Dorota Domińska-Werbel (2014) oraz Abdullah Alhurani i in. (2018) wykazały, że ocena sytuacji w kategoriach zagrożenia lub krzywdy/straty skłania jednostkę do stosowania strategii destruktywnej w postaci unikania konfrontacji z sytuacją trudną, nastawionej głównie na obniżenie przykrego napięcia emocjonalnego i łagodzenie negatywnych stanów emocjonalnych, wynikających z sytuacji trudnych. Także badania Geneviève Bouchard (2003) wskazują, że istotnym czynnikiem determinującym wybór postępowania w konflikcie jest sposób jego spostrzegania. Na podstawie uzyskanych wyników autorka ustaliła, że pary małżeńskie oceniające konflikt małżeński jako zagrożenie z większym prawdopodobieństwem wybierają strategie unikowe/dystansujące.

Prezentowane rezultaty badań dowodzą, że ocena sytuacji w kategorii zagrożenia lub krzywdy/straty skłania jednostkę do stosowania strategii uniku nastawionej jedynie na redukcję przykrego stanu napięcia i/lub osiągnięcia dobrego samopoczucia. Generalnie należy sądzić, że od wyniku oceny poznawczej sytuacji trudnej zależy, w jaki sposób adolescent poradzi sobie w sytuacji konfliktu społecznego, której doświadcza w środowisku szkolnym, grupie rówieśniczej oraz w domu rodzinnym.

W wielu sytuacjach trudnych zachowanie człowieka zależy nie tylko od cech samej sytuacji, na którą ma on zareagować, ale także od sposobu zachowania się innych ludzi znajdujących się w tej samej sytuacji. Środowiskiem stwarzającym naturalne warunki sprzyjające uczeniu się sposobów reagowania w odpowiedzi na sytuacje trudne jest rodzina, a rodzice są nierzadko pierwszymi modelami dla dziecka określonych strategii radzenia sobie z trudnościami. Główne wzory reagowania na trudności dziecko znajduje w zachowaniu się rodziców w sytuacjach napięć emocjonalnych oraz w ich ustosunkowaniu się do jego trudności i niepowodzeń w działaniu (Tyszkowa 1986). Wyniki badań Teresy Rostowskiej (1996) potwierdziły występowanie współzależności między rodzicami a dziećmi w zakresie najbardziej i najmniej preferowanych przez nich sposobów radzenia sobie w trudnych sytuacjach. W większości badanych rodzin zachodzi całkowite lub częściowe podobieństwo $\mathrm{w}$ ramach stosowanych przez nich sposobów radzenia sobie w sytuacjach trudnych, co jest przejawem transmisji międzypokoleniowej. Należy sądzić, że proces społecznego uczenia się przez modelowanie jest ważnym źródłem form reagowania człowieka na sytuacje trudne.

Wpływ rodziców odgrywających, najczęściej nieświadomie, role modeli nie zawsze dla dziecka bywa pozytywny. Wynikiem procesu uczenia się społecznego 
i wzorowania się na rodzicach są też formy reagowania na sytuacje trudne skoncentrowane na rezygnacji z realizacji dążenia do własnych celów pod wpływem trudności w działaniu i wycofaniu się z trudnej sytuacji interakcji społecznych. Zaniechanie realizacji własnych pragnień, brak stanowczości w obronie własnych spraw czy wycofanie się z kontaktów z innymi ludźmi i niepodejmowanie takich form aktywności, które by tych kontaktów wymagały, stanowią inercyjną formę nieśmiałości (Zabłocka 2012). Modelowanie odgrywa znaczącą rolę w genezie nieśmiałości u dzieci. Najsilniej oddziaływają wzorce rodzinne - „nieśmiałe dzieci mają nieśmiałych rodziców" (Bandelow 2011). Rodzice, którzy są nieśmiali, stają się modelami tego typu zachowań dla swoich dzieci. Dziecko, obserwując rodziców mających trudności w interakcjach społecznych, zwłaszcza gdy są oni przedmiotem identyfikacji, zaczyna wzorować się na nich. Badania Philipa Zimbardo (2011) wskazują, że tendencja do wycofania i unikania społecznych interakcji oraz niepowodzeń we właściwym uczestniczeniu w tych interakcjach u dorastających jest wyuczoną formą zachowania, nabytą w toku obserwacji i podczas częstych kontaktów z osobami z najbliższego otoczenia, przejawiającymi takie właśnie zachowania, tj. w wyniku oddziaływania modeli, najczęściej rodziców.

Należy sądzić, że strategia destruktywna u dziecka dorastającego w postaci unikania konfrontacji z sytuacją konfliktu społecznego kształtuje się pod wpływem wzorów reagowania na trudności, znajdujące się w zachowaniu rodziców w sytuacjach zawierających element zagrożenia realizacji dążeń czy osiągnięcia celu (zaspokojenia potrzeb).

\section{Problem i hipoteza badawcza}

Badania empiryczne skupiono wokół poznawczych i rodzinnych uwarunkowań strategii unikowego radzenia sobie młodzieży w sytuacji konfliktu społecznego, ze szczególnym zwróceniem uwagi na ocenę sytuacji konfliktu społecznego oraz wzoru reagowania rodziców na sytuację konfliktu społecznego. Zmierzały one do odpowiedzi na następujące pytanie badawcze:

1. Jaki zespół zmiennych poznawczych i rodzinnych ma związek ze strategią unikowego radzenia sobie młodzieży w sytuacji konfliktu społecznego?

Tak sformułowane pytanie badawcze pozwala na postawienie następującej hipotezy, której weryfikacji posłuży analiza wyników przeprowadzonych badań empirycznych:

H.1 Ocena sytuacji konfliktu jako zagrożenie lub jako krzywda/strata i prezentowana w sytuacji konfliktu społecznego strategia unikowego radzenia sobie rodziców (jednego lub obojga) współwystępuje ze strategią unikowego radzenia sobie młodzieży w sytuacji konfliktu społecznego 


\section{Metody badań własnych}

W badaniach zastosowano następujące metody:

Kwestionariusz Oceny Stresu (KOS) autorstwa Doroty Włodarczyk i Kazimierza Wrześniewskiego (2010) zawiera 35 (w tym 23 diagnostycznych) przymiotnikowych określeń oceniających sytuacje stresowe. Składa się z dwóch wersji, które obejmują te same zestawy przymiotnikowych określeń, a różnią się instrukcją podawaną osobom badanym. W wersji A (pomiar sytuacyjnej oceny stresu) osoby badane proszone są o wskazanie konkretnej sytuacji trudnej, która miała miejsce w ciągu ostatniego tygodnia (w opisanym badaniu była to sytuacja konfliktu społecznego). Wersja B (pomiar dyspozycyjnej oceny stresu) zawiera instrukcję, w której osoby badane proszone są o zaznaczenie, w jakim stopniu podane przymiotniki są zgodne z tym, czego najczęściej doświadczają w sytuacjach trudnych (w opisywanym badaniu były to sytuacje konfliktu społecznego). KOS składa się z sześciu podskal będących wskaźnikami poszczególnych rodzajów oceny stresu. Są to: zagrożenie-stan, zagrożenie-cecha, krzywda/strata-stan, krzywda/strata-cecha, wyzwanie-stan i wyzwanie-cecha. Podskale „zagrożenia” zawierają 10 pozycji, Podskale „wyzwanie” - 6 pozycji, a „krzywda/strata” - 4 pozycje. Kwestionariusz charakteryzuje się zadawalającą rzetelnością (współczynniki zgodności wewnętrznej $\alpha$ Cronbacha dla wersji A wynosi $0,76-0,90$, a dla wersji B - 0,79-0,90) oraz trafnością czynnikową i trafnością kryterialną.

Kwestionariusz Strategii Radzenia Sobie Rodziców w Sytuacji Konfliktu Społecznego (KSRwSK) Danuty Boreckiej-Biernat (2013) składa się z dwóch wersji: „Moja Matka” i „Mój Ojciec”. Przeznaczony jest do badania strategii radzenia sobie rodziców w sytuacji konfliktu społecznego, przy czym zachowania te poznawane są w percepcji ich dorastających dzieci. Narzędzie posiada opisy 16 sytuacji konfliktu społecznego w wersji „Moja Matka” i taką sama liczbę opisów w wersji „Mój Ojciec”. Do każdej sytuacji podano cztery zachowania wyrażające radzenie sobie rodziców w sytuacji konfliktu społecznego w percepcji ich dziecka: pierwsze odnosi się do agresywnego radzenia („A”), drugie do unikowego radzenia („U”), trzecie do uległego radzenia („Ul”), a czwarte do zadaniowego radzenia sobie w sytuacji konfliktu społecznego („Z”). Wyniki uzyskuje się dla każdej skali oddzielnie, poprzez sumowanie zaznaczonych zachowań w 16 sytuacjach należących do danej skali. Na potrzeby badań własnych wykorzystano Skalę („U”) Unikowego Radzenia Sobie Matki/Ojca w Sytuacji Konfliktu Społecznego. Kwestionariusz w wersji „Moja Matka” i „Mój Ojciec” charakteryzuje się dobrą rzetelnością (współczynnik zgodności wewnętrznej $\alpha$ Cronbacha wynosi około bądź powyżej 0,70) i trafnością diagnostyczną.

Kwestionariusz do badania strategii radzenia sobie młodzieży w sytuacji konfliktu społecznego (KSMK) opracowany przez D. Borecką-Biernat (2012) przeznaczony jest do badania strategii radzenia sobie w sytuacji konfliktu społecznego podejmo- 
wanej przez młodzież w wieku dorastania. Składa się z opisu 33 sytuacji konfliktu społecznego. Do każdej podano 4 zachowania wyrażające radzenie sobie z sytuacją konfliktu społecznego - pierwsze odnosi się do agresywnego radzenia („A”), drugie do unikowego radzenia („U”), trzecie do uległego radzenia („Ul”), a czwarte do zadaniowego radzenia sobie w sytuacji konfliktu społecznego („Z”). Wyniki uzyskuje się dla każdej skali oddzielnie poprzez sumowanie zaznaczonych zachowań w 33 sytuacjach należących do danej skali. Na potrzeby badań własnych wykorzystano Skalę („U”) Unikowego Radzenia Sobie Młodzieży w Sytuacji Konfliktu Społecznego. Kwestionariusz charakteryzuje się dobrą rzetelnością (współczynnik zgodności wewnętrznej $\alpha$ Cronbacha wynosi około bądź powyżej 0,70 ) i trafnością diagnostyczną.

\section{Osoby badane}

Przebadano grupę 468 dziewcząt i 425 chłopców w wieku 13-15 lat. Ogółem w przeprowadzonych badaniach wzięły udział 893 osoby. Badani byli uczniami pierwszych (150 dziewcząt i 415 chłopców), drugich (147 dziewcząt i 135 chłopców) i trzecich (157 dziewcząt i 129 chłopców) klas gimnazjalnych. Badania miały charakter grupowy, a przeprowadzono je na terenie szkół. Wszystkim badanym uczniom zapewniono dobrowolność udziału w badaniach i anonimowość, zaś badania zostały przeprowadzone zgodnie z zasadami psychologicznych badań naukowych.

Podstawowym kryterium doboru badanych uczniów był poziom wieku. Wpływ wieku na dobór strategii radzenia sobie w sytuacji konfliktu społecznego analizowano w grupie 13-15 lat (podokres wczesnej adolescencji). Wiek dorastania jest ważnym etapem w życiu każdego człowieka, ponieważ jest uważany za moment przejściowy między dzieciństwem a dorosłością. Określany jest też jako okres buntu i naporu. W nim dokonuje się wiele zmian biologicznych, psychicznych, mentalnych, motywacyjnych i w postawach społecznych, które sprawiają, że młodzież ma niejednokrotnie wiele problemów z dostosowaniem swojego postępowania do nowych sytuacji, zadań i ról społecznych (Czerwińska-Jasiewicz 2003). Ze względu na rozwój krytycznej oceny otaczającej rzeczywistości i wzmożone kształtowanie się obrazu własnej osoby, supremację sfery uczuciowej nad innymi dziedzinami życia psychicznego oraz nowe formy kontaktów społecznych i bezpośredniość w zachowaniu młodzież w wieku 13-15 lat wydaje się dobrym przedmiotem badań do poznania strategii unikowego radzenia sobie $\mathrm{w}$ sytuacji silnego napięcia emocjonalnego, jaką jest konflikt społeczny. 


\section{Analiza wyników badań}

W celu ustalenia, jaki zespół zmiennych osobowościowych i rodzinnych przewiduje poziom strategii unikowego radzenia sobie w sytuacji konfliktu społecznego u młodzieży, zdecydowano się na zastosowanie regresji $\mathrm{w}$ wariancie hierarchicznym z wykorzystaniem metody eliminacji wstecznej (kryterium: prawdopodobieństwo $\mathrm{F}$ - usunięcia $\geq 0,100$ ). Metoda polega na wprowadzeniu do modelu wszystkich predyktorów, a następnie sukcesywnym usuwaniu nieistotnych zmiennych, po których następuje ponowne przeliczanie modelu aż do uzyskania ostatecznej postaci (Bedyńska, Książek 2012). W grupie osób badanych wartości analizowanych zmiennych przyjmują rozkład normalny. Za zmienną zależną przyjęto wynik w skali „U” (unikowe radzenie sobie w sytuacji konfliktu społecznego) kwestionariusza KSMK. Jako zbiór zmiennych niezależnych potraktowano wyniki w sześciu skalach (zagrożenie-stan i zagrożenie-cecha, krzywda/strata-stan i krzywda/strata-cecha, wyzwanie-stan i wyzwanie-cecha) kwestionariusza KOS oraz w jednej skali „U” (unikowe radzenie sobie w sytuacji konfliktu społecznego) kwestionariusza KSRwSK w wersji „Moja Matka” i „Mój Ojciec”. Wyniki przedstawiono w tabeli 1.

Tabela 1. Krokowa regresja wielokrotna wyniku w skali Unik („U”) kwestionariusza KSRK względem skal kwestionariusza KOS i kwestionariusza KSRwSK w wersji „Moja Matka” i „Mój Ojciec": wyniki dla całej grupy $(\mathrm{N}=893)$ oraz dla dziewcząt $(\mathrm{N}=468)$ i chłopców $(\mathrm{N}=425)$

\begin{tabular}{|l|l|r|c|c|c|c|}
\hline $\begin{array}{c}\text { Osoby } \\
\text { badane }\end{array}$ & \multicolumn{1}{|c|}{ Zmienna } & Beta & B & Błąd st. B & t & $\begin{array}{c}\text { Poziom } \\
\mathrm{p}<\end{array}$ \\
\hline Ogółem & Zagrożenie-cecha & 0,09 & 0,04 & 0,02 & 2,90 & 0,004 \\
& Wyzwanie-cecha & $-0,08$ & 0,08 & 0,03 & 2,60 & 0,01 \\
& "U” Matka & 0,35 & 0,64 & 0,06 & 11,04 & 0,000000 \\
& W. wolny & & 1,47 & 0,31 & 4,71 & 0,000003 \\
\hline
\end{tabular}

Współczynnik korelacji wielokrotnej: $\mathrm{R}=0,37$

Współczynnik wielokrotnej determinacji: $\mathrm{R}^{2}=0,14$

Istotność równania: $\mathrm{F}(3,889)=46,33 ; \mathrm{p}<0,0000$

Błąd std. estymacji: 3,23

\begin{tabular}{|l|l|l|l|l|l|l|}
\hline Dziewczęta & Krzywda/Strata- & & & & & \\
& -cecha & 0,09 & 0,12 & 0,05 & 2,16 & 0,03 \\
& „U” Matka & 0,34 & 0,65 & 0,09 & 7,66 & 0,000000 \\
& W. wolny & & 1,82 & 0,35 & 5,17 & 0,000000 \\
\hline
\end{tabular}

Współczynnik korelacji wielokrotnej: $\mathrm{R}=0,36$

Współczynnik wielokrotnej determinacji: $\mathrm{R}^{2}=0,13$

Istotność równania: $\mathrm{F}(2,465)=35,12 ; \mathrm{p}<0,00000$

Błąd std. estymacji: 3,18 


\begin{tabular}{|l|l|r|r|r|l|l|}
\hline Chłopcy & Zagrożenie-cecha & 0,11 & 0,06 & 0,02 & 2,32 & 0,02 \\
& Wyzwanie-cecha & $-0,10$ & 0,09 & 0,04 & 2,20 & 0,03 \\
& „U” Matka & 0,35 & 0,61 & 0,08 & 7,61 & 0,000000 \\
& & 1,33 & 0,46 & 2,92 & 0,004 \\
\hline W. wolny & & & \\
\hline
\end{tabular}

Źródło: opracowanie własne.

Pierwszą analizę przeprowadzono na wynikach całej grupy badanej młodzieży, bez względu na płeć. Jak widać w tabeli 1, trzy zmienne miały istotny wpływ na strategię unikowego radzenia sobie młodzieży w sytuacji konfliktu społecznego: dyspozycyjna ocena konfliktu jako zagrożenie, dyspozycyjna ocena konfliktu jako wyzwanie i strategia uniku matki. Współczynnik korelacji wielokrotnej wynosi $\mathrm{R}=0,37$ i wskazuje, że związek liniowy między strategią unikowego radzenia sobie młodzieży w sytuacji konfliktu społecznego a łącznym wpływem wymienionych zmiennych jest niski. Zmienne te wyjaśniają 14\% wariancji zmiennej zależnej $\left[\mathrm{R}^{2}=0,14 ; \mathrm{F}(3,889)=46,33 ; \mathrm{p}<0,000000\right]$. Pozostałe zmienne uwzględnione $\mathrm{w}$ badaniu okazały się nieistotnymi wyznacznikami strategii unikowej w grupie młodzieży. Wartości Beta wskazują, że im wyższy poziom dyspozycyjnej oceny konfliktu jako zagrożenie, niższy poziom dyspozycyjnej oceny konfliktu jako wyzwanie oraz wyższy poziom strategii unikowego radzenia sobie matki w sytuacji konfliktu społecznego, tym wyższy poziom strategii unikowego radzenia sobie dorastających w sytuacji konfliktu społecznego.

Przeprowadzono odrębne analizy dla grup wydzielonych ze względu na płeć (por. tabela 1). Krokowa analiza regresji wykazała, że spośród ośmiu zmiennych niezależnych wprowadzonych do modelu regresji dwie miały istotne znaczenie w wyjaśnianiu strategii unikowego radzenia sobie, stosowanej przez dziewczęta w sytuacji konfliktu społecznego. Pozostałe zmienne uwzględnione w badaniu okazały się nieistotnymi wyznacznikami strategii unikowego radzenia sobie dziewcząt. Z obliczeń wynika, że ważną rolę, determinującą strategie unikowego radzenia sobie przez dziewczęta odgrywa: dyspozycyjna ocena konfliktu jako krzywda/strata i strategia unikowego radzenia sobie matki. Współczynnik korelacji wielokrotnej wynosi $\mathrm{R}=0,36$ i wskazuje, że związek liniowy między strategią unikowego radzenia sobie dziewcząt w sytuacji konfliktu społecznego a łącznym wpływem wymienionych zmiennych jest niski. 13\% wariancji zmiennej zależnej wyjaśniają te zmienne niezależne $\left[\mathrm{R}^{2}=0,13, \mathrm{~F}(2,465)=35,12 ; \mathrm{p}<0,00000\right]$. Parametry równania regresyjnego, w tym jego istotność, świadczą o tym, że im wyższy poziom dyspozycyjnej oceny konfliktu jako krzywda/strata i wyższy poziom 
strategii unikowego radzenia sobie matki w sytuacji konfliktu społecznego, tym wyższy poziom strategii unikowego radzenia sobie dziewcząt w sytuacji konfliktu społecznego.

Sprawdzono też, jaki zespół zmiennych osobowościowych i rodzinnych ma wpływ na poziom strategii unikowego radzenia sobie chłopców w sytuacji konfliktu społecznego. Trzy zmienne niezależne okazały się istotne w równaniu regresyjnym. Są nimi: dyspozycyjna ocena konfliktu jako zagrożenie, dyspozycyjna ocena konfliktu jako wyzwanie i strategia unikowego radzenia sobie matki. Współczynnik korelacji wielokrotnej wynosi $\mathrm{R}=0,38$ i wskazuje, że związek liniowy między strategią unikowego radzenia sobie chłopców w sytuacji konfliktu społecznego a łącznym wpływem wymienionych zmiennych jest niski. Współczynnik wielokrotnej determinacji $R^{2}=0,14[F=(3,421)=23,16 ; p<0,00000]$ i wskazuje, że $14 \%$ zmienności w zakresie strategii unikowego radzenia sobie chłopców w sytuacji konfliktu społecznego daje się wyjaśnić oddziaływaniem przyjętego zespołu zmiennych niezależnych. Pozostałe zmienne uwzględnione $\mathrm{w}$ badaniu okazały się nieistotnymi wyznacznikami strategii uniku w grupie chłopców. Wartości Beta świadczą, że im wyższy poziom dyspozycyjnej oceny konfliktu jako zagrożenie, niższy poziom dyspozycyjnej oceny konfliktu jako wyzwanie oraz wyższy poziom strategii unikowego radzenia sobie matki w sytuacji konfliktu społecznego, tym wyższy poziom strategii unikowego radzenia sobie chłopców w sytuacji konfliktu społecznego.

W świetle dokonanej weryfikacji statystycznej można stwierdzić, że uzyskane wyniki pozwoliły zweryfikować słuszność przedstawionej hipotezy H.1. Warto zaznaczyć, że wyodrębnione zmienne osobowościowe i rodzinne nie są silnymi predyktorami strategii unikowego radzenia sobie młodzieży w sytuacji konfliktu społecznego, o czym świadczy wynik $\mathrm{R}^{2}=0,13-0,14$. Biorąc pod uwagę stosunkowo niski współczynnik wielokrotnej determinacji, nasuwa się wniosek, że może istnieć wiele innych zmiennych współdeterminujących poziom strategii unikowego radzenia młodzieży w sytuacji konfliktu społecznego, które nie zostały uwzględnione w tym badaniu. Obszarem wartym dalszej eksploracji naukowej może być prowadzenie podobnych badań w odniesieniu do temperamentalnej natury funkcjonowania jednostki w konflikcie. Nie należy jednak wykluczyć, że rezultaty tych badań mogą wnieść nową wiedzę do zagadnień związanych z konfliktem i sztuki rozwiązywania sporów.

\section{Podsumowanie wyników badań}

Istotnym czynnikiem determinującym wybór postępowania $\mathrm{w}$ konflikcie jest sposób jego postrzegania (Reykowski 2002). Młodzież wykorzystująca strategię uniku w sytuacji konfliktu społecznego charakteryzuje się wyższą dyspozycyjną oceną konfliktu w kategorii zagrożenie lub krzywda/strata. W badaniach stwier- 
dzono, że skutkiem poczucia zagrożenia utraty wartości materialnych lub osobistych, np. pozycji społecznej, które mogą dopiero zaistnieć, a w obecnym stanie są dopiero antycypowane, bądź zaistniałych szkód i strat, związanych z ważnymi obiektami i przedmiotami w sytuacji konfliktu społecznego, może być skłonność do unikania aktywnego działania w obliczu konfliktu przez angażowanie się w inne bezstresowe formy aktywności, nastawione na obniżenie przykrego napięcia emocjonalnego, a nie na rozwiązanie problemu. Jak widać, strategia ta jest właściwie decyzją, czy warto angażować się w konflikt, czy nie, podczas podejmowania której poddawane są ocenie możliwe zyski i straty (Antonini 1998). Jest ona preferowana w sytuacji, gdy koszty bądź ryzyko angażowania się w konflikt jest duże, a możliwe zyski niewystarczające. W momencie, gdy młody człowiek spostrzega, że działanie partnera doprowadziło już do pewnych szkód związanych na przykład z poczuciem własnej wartości, jest on skłonny wycofać się z sytuacji konfliktu. Tłumaczy to niejako uzyskane związki tej strategii z oceną konfliktu jako zagrożenie, gdy ryzyko jest duże, oraz z oceną konfliktu jako krzywda/strata, gdy już jednostka nie ma nic do zdobycia i jest przekonana o nieodwracalności tej sytuacji. Ucieczka z sytuacji konfliktu prowadzi do zaniechania celów działań pod wpływem trudności. Cel „osiągnąć to a to” zostaje zastąpiony przez cel „obniżyć nieprzyjemne napięcie emocjonalne" (Maruszewski 1981). Unikanie konfrontacji z konfliktem polegające na podjęciu przez jednostkę dodatkowych czynności angażujących uwagę (oglądanie telewizji, objadanie się, spanie), odwracających ją od sytuacji konfliktu, jak i na poszukiwaniu kontaktów z innymi ludźmi jest wyrazem obrony własnej osoby przed sytuacją zagrożenia bądź zaistniałą szkodą w postaci utraty wartości materialnych lub osobistych, np. prestiż społeczny (Heszen-Niejodek 2002). Zarysowująca się taka tendencja wydaje się być zgodna z wynikami uzyskanymi przez Mikulincera i Florian (1995), Anshelda i Wellsa (2000), Bouchard (2003), Włodarczyk i Wrześniewskiego (2010), Domińską-Werbel (2014) i Alhurani i in. (2018).

Badania wykazały także, że unikowy sposób reagowania na napięcie emocjonalne, powstający w sytuacji konfliktu społecznego, kształtuje się w sytuacji wychowawczej, w której matka stosująca strategię opartą na unikaniu przyczynia się do modelowania u córki i syna strategii polegającej na unikowym zachowaniu, wykorzystywanej w sytuacji konfliktu społecznego. Matka dostarcza dorastającemu dziecku unikowych wzorów reagowania na konflikt. Uczy się ono tych wzorów przez obserwowanie zachowań matki w warunkach zagrożenia realizacji jego własnych dążeń. Ponadto analiza przedstawionych wyników ujawniła, że dla nasilenia strategii radzenia sobie młodzieży w sytuacji rozbieżności dążeń nie ma znaczenia strategia unikowego radzenia sobie stosowana w sytuacji konfliktu społecznego przez ojców. Niezależnie od tego, czy ojcowie radzą sobie unikowo w sytuacji konfliktu społecznego, czy też nie, dorastający mają matki, które stosują strategię unikowego radzenia sobie w sytuacji konfliktu społecznego. Warto też zwrócić uwagę na preferencję oddziaływań sprzyjających strategii uniku radzenia 
sobie wśród chłopców w wieku dorastania przez rodzica odmiennej płci. Świadczy to o tym, że na unikowe radzenie sobie w sytuacji konfliktu społecznego chłopca wpływają przede wszystkim cechy osobowe rodzica, z którym dziecko się utożsamia, nie zaś fakt zgodności płci modela i osoby z nim się identyfikującej. Z kolei unikowa strategia radzenia sobie wykorzystywana przez dziewczęta w sytuacji konfliktu społecznego kształtuje się pod wpływem stosowania przez matki takiej właśnie strategii. Powołajmy się na mechanizm identyfikacji dzieci z rodzicami tej samej płci: dziewczęta identyfikują się z matkami, więc ich unikowy wzór reagowania na trudności silnie oddziałuje na kształtowanie się strategii radzenia sobie w sytuacjach konfliktu społecznego córek. Opierając się na tych wynikach, można stwierdzić, że wysoki poziom wycofania się młodego człowieka z sytuacji konfliktu jest wyuczoną formą zachowania, wynikającą z obserwacji i częstego kontaktu z matką przejawiającą takie właśnie zachowanie, tj. na skutek oddziaływania matki funkcjonującej jako model do naśladowania. Poglądy te wydają się potwierdzać wyniki badań przeprowadzone przez D. Borecką-Biernat (2006) i Agnieszkę Filip (2010).

Uogólniając powyższe wyniki, należy sądzić, że poznawcza ocena młodego człowieka sytuacji konfliktu społecznego może mieć wpływ na wybór strategii rozwiązywania konfliktu. Gdy sytuacja konfliktu społecznego postrzegana jest jako zagrożenie lub krzywda/strata, dorastający częściej stosuje strategie unikowego radzenia sobie, by poradzić sobie z tą sytuacją. Nie sposób jednakże nie zauważyć, że dziecko dorastające uczy się strategii unikowego radzenia sobie w sytuacji konfliktu społecznego między innymi przez obserwowanie rodzica, który przejawia ten sposób radzenia sobie w sytuacjach konfliktu społecznego i częsty z nim kontakt. Zatem „dom rodzinny” uczy młodego człowieka strategii unikowego radzenia sobie w sytuacji konfliktu społecznego.

\section{Bibliografia}

Alhurani A., Dekker R., Ahmad M., Miller J., Yousef K., Abdulqader B., Salami I., Lennie T., Randall D., Moser D. (2018) Stress, cognitive appraisal, coping, and event free survival in patients with heart failure, „Heart and Lung”, nr 47 (3), s. 205-210.

Anshel M., Wells B. (2000) Personal and Situational Variables that Describe Coping with Acute Stress in Competitive Sport, „Journal of Social Psychology”, nr 140 (4), s. 434-450.

Antonini D. (1998) Relationship Between the Big Five Personality Factors and Conflict Management Styles, „International Journal of Conflict Management”, nr 9 (4), s. 336-355.

Balawajder K. (2010) Zachowania uczestników konfliktu interpersonalnego w: Sytuacje konfliktu w środowisku rodzinnym, szkolnym i rówieśniczym. Jak sobie radzq 
z nimi dzieci i młodzież?, D. Borecka-Biernat (red.), Warszawa, Wydawnictwo Difin, s. $137-179$.

Bandelow B. (2011) Nieśmiałość. Czym jest i jak ja pokonać, tłum. M. L. Kalinowski, Gdańsk, Gdańskie Wydawnictwo Psychologiczne.

Bedyńska S., Książek M. (2012) Praktyczny przewodnik wykorzystania modeli regresji oraz równań strukturalnych, Warszawa, Akademickie Sedno.

Borecka-Biernat D. (2006) Strategie radzenia sobie młodzieży $w$ trudnych sytuacjach społecznych. Psychospołeczne uwarunkowania, Wrocław, Wydawnictwo Uniwersytetu Wrocławskiego.

Borecka-Biernat D. (2012) Kwestionariusz strategii radzenia sobie młodzieży w sytuacji konfliktu społecznego, „Psychologia Wychowawcza”, nr 1-2, s. 86-118.

Borecka-Biernat D. (2013) Kwestionariusz strategii radzenia sobie rodziców w sytuacjach konfliktu społecznego w percepcji dziecka w: Drogi rozwoju psychologii wrocławskiej. Tom jubileuszowy z okazji 45-lecia studiów psychologicznych $w$ Uniwersytecie Wrocławskim, M. Straś-Romanowska (red.), Wrocław, Wydawnictwo Uniwersytetu Wrocławskiego, s. 223-245.

Bouchard G. (2003) Cognitive Appraisals, Neuroticism, and Openness as Correlates of Coping Strategies: An Integrative Model of Adaptation to Marital Difficulties, „Canadian Journal of Behavioural Science", nr 1 (35), s. 1-12.

Cylkowska-Nowak M., Augustyn T. (2014) Obraz szkoły w świadomości uczniów. Reprezentacje konfliktu $w$ dwóch badaniach jakościowych $\mathrm{w}$ : Rozwiqzywanie sytuacji konfliktowych $w$ wymiarze jednostkowym i społecznym, M. Plucińska (red.), Poznań, Wydawnictwo Naukowe Wydziału Nauk Społecznych UAM, s. 183-200.

Czerwińska-Jasiewicz M. (2003) Społeczno-kulturowe podejście do dorastania w: Z zagadnień współczesnej psychologii wychowawczej, A. Jurkowski (red.), Warszawa, Wydawnictwo Instytutu Psychologii PAN, s. 208-226.

Deutsch M., Coleman P. (2005) Rozwiązywanie konfliktów. Teoria i praktyka, tłum. M. Cierpisz, Kraków, Wydawnictwo Uniwersytetu Jagiellońskiego.

Domińska-Werbel D. (2014) Psychologiczne uwarunkowania strategii radzenia sobie młodzieży gimnazjalnej $w$ trudnych sytuacjach społecznych, Legnica, Wydawnictwo Państwowej Wyższej Szkoły Zawodowej.

Filip A. (2010) Sposoby rozwiq̨zywania konfliktów rodzinnych w percepcji młodzieży różniq̨cej się korzystaniem z mediów w: Sytuacje konfliktu w środowisku rodzinnym, szkolnym i rówieśniczym. Jak sobie radzq z nimi dzieci i młodzież?, D. Borecka-Biernat (red.), Warszawa, Wydawnictwo Difin, s. 207-223. 
Gurba E. (2013) Nieporozumienia z dorastającymi dziećmi w rodzinie. Uwarunkowania i wspomaganie, Kraków, Wydawnictwo Uniwersytetu Jagiellońskiego.

Guszkowska M., Gorący A., Rychta-Siedlecka J. (2001) Ważne zdarzenia życiowe i codzienne kłopoty jako źródło stresu w percepcji młodzieży, „Edukacja Otwarta”, nr 4, s. $155-164$.

Heszen-Niejodek I. (2000) Teoria stresu psychologicznego i radzenia sobie w: Psychologia. Podręcznik akademicki, J. Strelau (red.), Gdańsk, Gdańskie Wydawnictwo Psychologiczne, t.. 3, s. 465-493.

Heszen-Niejodek I. (2002) Emocje, ocena poznawcza i strategie $w$ procesie radzenia sobie w: Teoretyczne i kliniczne problemy radzenia sobie ze stresem, I. Heszen-Niejodek (red.), Poznań, Wydawnictwo Stowarzyszenie Psychologia i Architektura, s. $174-197$.

Jaworski R. (2000) Konflikt pokoleń w okresie adolescencji. Psychologiczne aspekty radzenia sobie ze stresem w: Problemy człowieka w świecie psychologii, R. Jaworski, A. Wielgus, J. Łukjaniuk (red.), Płock, Wydawnictwo Naukowe NOVUM, s. 27-54.

Kłusek-Wojcisze B. (2009) Kwestionariusz stylów rozwiązywania konfliktów, „Czasopismo Psychologiczne", nr 15 (1), s. 119-140.

Kobus K., Reyes O. (2000) A descriptive study of urban Mexican American adolescents' perceived stress and coping, „Hispanic Journal of Behavioral Sciences”, nr 22, s. $163-178$.

Kowalski K., Crocker P., Hoar S. (2005) Adolescent's control beliefs and doping with stress in sport, „International Journal of Sport Psychology”, nr 36 (4), s. 257-272.

Lachowska B. (2010) Style rozwiq̨zywania konfliktów i ich efekty w relacji między rodzicami i adolescentami - prezentacja narzędzi pomiaru w: Sytuacje konfliktu w środowisku rodzinnym, szkolnym i rówieśniczym. Jak sobie radzq z nimi dzieci i młodzież?, D. Borecka-Biernat (red.), Warszawa, Wydawnictwo Difin, s. 180-206.

Maruszewski T. (1981) Mechanizmy zwalczania stresu egzaminacyjnego i ich indywidualne wyznaczniki, Poznań, Wydawnictwo UAM.

Mikołowska G. (2012) Agresja w okresie dorastania-charakterystyka, przejawy, przeciwdziałanie w: Zagrożenia okresu dorastania, Z. Izdebski (red.), Zielona Góra, Wydawnictwo U.Z., s. 91-110.

Mikołowska-Olejniczak G. (2002) Szkolne uwarunkowania zachowań agresywnych dzieci i młodzieży w: Modelowe rozwiq̨zania działalności profilaktycznej w grupach dzieci i młodzieży, A. Doliński (red.), Zielona Góra, Komenda Chorągwi Ziemi Lubuskiej ZHP, s. 57-70. 
Mikulincer M., Victor F. (1995) Appraisal of and coping with real-life stressful situation: The contribution of attachment styles, „Personality and Social Psychology Bulletin", nr 21 (4), s. 406-415.

Olubiński A. (1992) Konflikty rodzice - dzieci. Dramat czy szansa, Toruń, Wydawnictwo Adam Marszałek.

Pisula E., Sikora R. (2008) Wiek i płeć a radzenie sobie ze stresem przez młodzież w wieku 12-17 lat, „Przeglad Psychologiczny”, nr 4, s. 405-422.

Polak K. (2010) Uczeń w sytuacji konfliktów szkolnych w: Sytuacje konfliktowe w środowisku rodzinnym, szkolnym i rówieśniczym, D. Borecka-Biernat (red.), Warszawa, Wydawnictwo Difin, s. 23-40.

Reykowski J. (1988) Źródła procesów ewaluatywnych i ich funkcje regulacyjne w: Studia nad procesami wartościowania, B. Wojciszke (red.), Wrocław, Ossolineum, s. 36-54.

Reykowski J. (2002) Psychological meaning of democracy and resolving the social coordination problems, „Polish Psychological Bulletin”, nr 4, s. 19-30.

Rostowska T. (1996) Transmisja międzypokoleniowa $w$ rodzinie $w$ zakresie zachowań agresywnych, „Przegląd Psychologiczny”, nr 39 (1-2), s. 177-186.

Różańska-Kowal J. (2004) Szkoła jako główne źródło stresu młodzieży w wieku dorastania, „Kwartalnik Pedagogiczny”, nr 3, s. 203-214.

Sikora R., Pisula E., (2002) Przyczyny stresu i strategie radzenia sobie ze stresem u młodzieży w wieku 14-16 lat, „Polskie Forum Psychologiczne”, nr 2 (2), s. 110-122.

Trzebiński J. (1985) Rola schematów poznawczych w zachowaniach społecznych w: Psychologia spostrzegania społecznego, M. Lewicka, J. Trzebiński (red.), Warszawa, Książka i Wiedza, s. 257-364.

Tyszkowa M. (1986) Zachowanie się dzieci w sytuacjach trudnych, Warszawa, Państwowe Wydawnictwo Naukowe.

Walęcka-Matyja K. (2015) Obraz wybranych sytuacji konfliktowych i sposobów ich rozwiazywania w percepcji rodziców adolescentów - analiza psychologiczna w: Sytuacje konfliktu społecznego. Przyczyny - sposoby rozwiq̨zywania - skutki, D. Borecka-Biernat (red.), Wrocław, Wydawnictwo Uniwersytetu Wrocławskiego, s. 171-184.

Węglińska A. (2007) Nowe media w sytuacji zagrożenia i konfliktu, „Rocznik Bezpieczeństwa Międzynarodowego", nr 2, s. 202-210.

Winstok Z. (2007) Perceptions, emotions, and behavioral decisions in conflicts that escalate to Violetce, „Motivation and Emotion”, nr 31 (2), s. 125-136. 
Włodarczyk D. (1999) Rola i miejsce oceny poznawczej w radzeniu sobie ze stresem, „Nowiny Psychologiczne”, nr 4, s. 57-73.

Włodarczyk D., Wrześniewski K. (2005) Ocena stresu w kategoriach wyzwania u chorych po zawale serca - próba syntezy na podstawie danych empirycznych, „Przegląd Psychologiczny", nr 48, s. 339-358.

Włodarczyk D., Wrześniewski K. (2010) Kwestionariusz Oceny Stresu (KOS), „Przegląd Psychologiczny", nr 4, s. 479-496.

Wojciszke B. (1988) Wpływ schematów na procesy ewaluacji w: Studia nad procesami wartościowania, B. Wojciszke (red.), Wrocław, Ossolineum, s. 54-86.

Wrześniewski K. (1996) Style a strategie radzenia sobie ze stresem. Problemy pomiaru w: Człowiek $w$ sytuacji stresu. Problemy teoretyczne i metodologiczne, I. Heszen-Niejodek, Z. Ratajczak (red.), Katowice, Wydawnictwo Uniwersytetu Śląskiego, s. 44-64.

Zabłocka A. (2012) Zrozumieć nieśmiałość. Aspekty diagnostyczne i terapeutyczne, Bydgoszcz, Wydawnictwo Uniwersytetu Kazimierza Wielkiego.

Zimbardo P. (2011) Nieśmiałość. Co to jest? Jak sobie z niq radzić?, tłum. A. Sikorzyńska, Warszawa, Wydawnictwo Naukowe PWN. 